\title{
SCHEDULE CONTINGENCY ANALYSIS FOR TRANSIT PROJECTS USING A SIMULATION APPROACH
}

\author{
Asli Pelin GURGUN ${ }^{\mathrm{a}}$, Ye ZHANG ${ }^{\mathrm{b}}$, Ali TOURAN ${ }^{\mathrm{b}}$ \\ ${ }^{a}$ Department of Civil Engineering, Okan University, Tuzla Campus, 34959, Akfirat-Tuzla, \\ Istanbul, Turkey \\ ${ }^{b}$ Department of Civil and Environmental Engineering, Northeastern University, 360 Huntington Avenue, \\ Boston, MA 02115, USA
}

Received 27 Jun. 2011; accepted 2 Nov. 2011

\begin{abstract}
This paper presents a probabilistic method to establish schedule contingency levels based on percent completion of the project. The objective is providing a distribution for contingency for various percent completion levels which allows the project owner/manager to choose the schedule contingency at their comfort level. The proposed method is applied on real data from a number of US transit projects and actual schedule overruns for different phases of the project development (preliminary engineering, final design and construction) are analyzed. These values are used to establish the required contingency at the conclusion of each of the mentioned project phases. Additionally, using these values, the required contingency at various points during the construction phase (such as $25 \%$ and $50 \%$ completion) is calculated and reported. This approach can be used by project owners to plan realistic schedules during various phases of the project, providing better control on duration and the opportunity for being prepared to take necessary action in case the available schedule contingency falls below reasonable levels.
\end{abstract}

Keywords: contingency; simulation; schedule; transportation; transit projects; overrun; delay; risk.

Reference to this paper should be made as follows: Gurgun, A. P.; Zhang, Y.; Touran, A. 2013. Schedule contingency analysis for transit projects using a simulation approach, Journal of Civil Engineering and Management 19(4): 465-475. http://dx.doi.org/10.3846/13923730.2013.768542

\section{Introduction}

Schedule delays and cost overruns are challenging for large-scale construction projects with long durations. Uncertainties embedded in such projects affect both schedule and cost (Tseng et al. 2009). Project delays are common in practice and the amount of delay vary with the nature of the project. In construction, delay could be defined as the time overrun either beyond completion date specified in a contract, or beyond the date that parties agreed upon delivery of a project (Assaf, AlHejji 2006). The delays are usually accompanied by cost overruns and the problem is experienced by both developed and developing countries (Kaliba et al. 2009). Cost overrun and time overrun generally result from factors that occur at various phases of the project life cycle (Bhargava et al. 2010). Delays in construction projects are a universal phenomenon and develop slowly during the course of the work (Ahmed et al. 2003). Causes of delay in large construction projects, average of time overrun is between $10 \%$ and $30 \%$ of original duration (Assaf, Al-Hejji 2006).
It is clear that the complex nature and immense size of the large-scale projects require effective planning (Capka 2004). Project managers should know the probability of time overrun in order to take necessary corrective actions. One obvious planning approach is to use this information to include sufficient contingency for the project schedule. Other corrective actions may include but not limited to a change of project delivery method (Design Build vs Design Bid Build, etc.), use of new equipment or technology, redrafting dispute resolution procedures and expediting construction permits. Therefore, a distinct need has emerged to develop facilitated methods for evaluating the probability of construction time overruns (Luu et al. 2009).

The causes of undesired growths in schedule and cost have attracted construction management researchers worldwide and many reports and research studies can be found in the literature. The issue of optimism bias in organizational dynamics in construction and concluded that it is imperative to have 


\begin{tabular}{|c|c|c|c|c|c|c|c|c|c|c|c|}
\hline \multirow[b]{2}{*}{ A } & \multirow[b]{2}{*}{ B } & \multicolumn{3}{|c|}{$\begin{array}{c}\text { Original project duration } \\
\text { by phase (years) }\end{array}$} & \multirow[b]{2}{*}{$\mathrm{F}$} & \multicolumn{3}{|c|}{$\begin{array}{c}\text { Approximate project delay by } \\
\text { phase (years) }\end{array}$} & \multirow[b]{2}{*}{$\mathrm{J}$} & \multirow[b]{2}{*}{$\mathrm{K}$} & \multirow[b]{2}{*}{$\mathrm{L}$} \\
\hline & & $\mathrm{C}$ & $\mathrm{D}$ & $\mathrm{E}$ & & G & $\mathrm{H}$ & I & & & \\
\hline $\begin{array}{l}\text { Project } \\
\text { Number }\end{array}$ & Case study projects & $\begin{array}{l}\mathrm{PE} / \\
\mathrm{FEIS}\end{array}$ & FD & Construction & $\begin{array}{c}\text { Original total } \\
\text { project duration } \\
(\text { Col.C }+ \text { Col.D }+ \\
\text { Col.E })\end{array}$ & $\begin{array}{c}\text { PE/ } \\
\text { FEIS } \\
\text { delay }\end{array}$ & $\begin{array}{l}\text { FD } \\
\text { delay }\end{array}$ & $\begin{array}{l}\text { Construction } \\
\text { delay }\end{array}$ & $\begin{array}{c}\text { Total project delay } \\
(\text { Col.G }+ \text { Col. } \mathrm{H}+\text { Col.I })\end{array}$ & $\begin{array}{c}\text { Final duration } \\
(\text { Col.F }+ \\
\text { Col.G }+ \\
\text { Col.H }+ \text { Col.I })\end{array}$ & $\begin{array}{c}\text { Schedule overrun } \\
\text { changes for total } \\
\text { project \% (Col.K - } \\
\text { Col.F)/(Col.F) }\end{array}$ \\
\hline 1 & $\begin{array}{l}\text { Atlanta North Line } \\
\text { Extension }\end{array}$ & 1 & 3 & 6 & 10 & 0 & 0 & 4 & 4 & 14 & 40 \\
\hline 2 & $\begin{array}{l}\text { Boston Old Colony } \\
\text { Rehabilitation }\end{array}$ & 1 & 6 & 2 & 9 & 1 & 2 & 0 & 3 & 12 & 33 \\
\hline 3 & $\begin{array}{l}\text { Boston Silver Line } \\
\text { (Phase 1) }\end{array}$ & 1 & 1 & 10 & 12 & 4 & 0 & 4 & 8 & 20 & 67 \\
\hline 4 & $\begin{array}{l}\text { Chicago Southwest } \\
\text { Extension }\end{array}$ & 2 & 3 & 3 & 8 & 0 & 1 & 2 & 3 & 11 & 38 \\
\hline 5 & $\begin{array}{l}\text { Dallas South Oak } \\
\text { Cliff Extension }\end{array}$ & 2 & 1 & 3 & 6 & 1 & 2 & -1 & 2 & 8 & 33 \\
\hline 6 & $\begin{array}{l}\text { Denver Southwest } \\
\text { Line }\end{array}$ & 4 & 1 & 3 & 8 & 4 & 0 & 0 & 4 & 12 & 50 \\
\hline 7 & $\begin{array}{l}\text { Los Angeles Red } \\
\text { Line MOS } 1\end{array}$ & & 5 & 1 & 6 & & 1 & 2 & 3 & 9 & 50 \\
\hline 8 & $\begin{array}{l}\text { Los Angeles Red } \\
\text { Line MOS } 2\end{array}$ & & 7 & 4 & 11 & & 2 & 2 & 4 & 15 & 36 \\
\hline 9 & $\begin{array}{l}\text { Los Angeles Red } \\
\text { Line MOS } 3\end{array}$ & & 10 & 5 & 15 & & 2 & 1 & 3 & 18 & 20 \\
\hline 10 & $\begin{array}{l}\text { Minneapolis } \\
\text { Hiawatha Line }\end{array}$ & 6 & 1 & 4 & 11 & 3 & 1 & 1 & 5 & 16 & 45 \\
\hline 11 & $\begin{array}{l}\text { New-Jersey Hudson- } \\
\text { Bergen MOS1 }\end{array}$ & 3 & 1 & 5 & 9 & 1 & 1 & 2 & 4 & 13 & 44 \\
\hline 12 & $\begin{array}{l}\text { New York 63rd } \\
\text { Street Connector }\end{array}$ & 3 & 2 & 7 & 12 & 3 & 1 & 0 & 4 & 16 & 33 \\
\hline 13 & Pasadena Gold Line & 3 & 4 & 3 & 10 & 2 & 4 & 0 & 6 & 16 & 60 \\
\hline 14 & $\begin{array}{l}\text { Pittsburgh Airport } \\
\text { Busway (Phase 1) }\end{array}$ & 2 & 1 & 7 & 10 & 4 & 3 & 0 & 7 & 17 & 70 \\
\hline 15 & $\begin{array}{l}\text { Portland Airport } \\
\text { MAX Extension }\end{array}$ & & 2 & 4 & 6 & & 0 & 0 & 0 & 6 & 0 \\
\hline 16 & $\begin{array}{l}\text { PortlandBanfield } \\
\text { Corridor }\end{array}$ & & 3 & 1 & 4 & & 2 & 0 & 2 & 6 & 50 \\
\hline
\end{tabular}




\begin{tabular}{|c|c|c|c|c|c|c|c|c|c|c|c|}
\hline \multirow[b]{2}{*}{ A } & \multirow[b]{2}{*}{ B } & \multicolumn{3}{|c|}{$\begin{array}{c}\text { Original project duration } \\
\text { by phase (years) }\end{array}$} & \multirow[b]{2}{*}{$\mathrm{F}$} & \multicolumn{3}{|c|}{$\begin{array}{c}\text { Approximate project delay by } \\
\text { phase (years) }\end{array}$} & \multirow[b]{2}{*}{$\mathbf{J}$} & \multirow[b]{2}{*}{$\mathrm{K}$} & \multirow[b]{2}{*}{$\mathrm{L}$} \\
\hline & & $\mathrm{C}$ & $\mathrm{D}$ & $\mathrm{E}$ & & $\mathrm{G}$ & $\mathrm{H}$ & I & & & \\
\hline $\begin{array}{l}\text { Project } \\
\text { Number }\end{array}$ & Case study projects & $\begin{array}{l}\text { PE/ } \\
\text { FEIS }\end{array}$ & FD & Construction & $\begin{array}{c}\text { Original total } \\
\text { project duration } \\
(\text { Col. } \mathrm{C}+\mathrm{Col} . \mathrm{D}+ \\
\text { Col.E })\end{array}$ & $\begin{array}{l}\text { PE/ } \\
\text { FEIS } \\
\text { delay }\end{array}$ & $\begin{array}{l}\text { FD } \\
\text { delay }\end{array}$ & $\begin{array}{l}\text { Construction } \\
\text { delay }\end{array}$ & $\begin{array}{c}\text { Total project delay } \\
(\text { Col. } G+\text { Col.H }+ \text { Col.I })\end{array}$ & $\begin{array}{l}\text { Final duration } \\
\quad(\text { Col.F }+ \\
\text { Col.G }+ \\
\text { Col.H }+ \text { Col.I })\end{array}$ & $\begin{array}{c}\text { Schedule overrun } \\
\text { changes for total } \\
\text { project } \%(\text { Col.K - } \\
\text { Col.F }) /(\text { Col.F })\end{array}$ \\
\hline 17 & $\begin{array}{l}\text { Portland Interstate } \\
\text { MAX }\end{array}$ & 1 & 2 & 2 & 5 & 0 & 0 & 0 & 0 & 5 & 0 \\
\hline 18 & $\begin{array}{l}\text { Portland Westside/ } \\
\text { Hillsboro MAX }\end{array}$ & 1 & 3 & 4 & 8 & 1 & 3 & 0 & 4 & 12 & 50 \\
\hline 19 & $\begin{array}{l}\text { Salt Lake North- } \\
\text { South Line }\end{array}$ & 1 & 3 & 1 & 5 & 2 & 0 & -1 & 1 & 6 & 20 \\
\hline 20 & $\begin{array}{l}\text { San Fransisco SFO } \\
\text { Airport Exten. }\end{array}$ & 4 & 1 & 6 & 11 & 2 & 0 & 2 & 4 & 15 & 36 \\
\hline 21 & $\begin{array}{l}\text { San Juan Tren } \\
\text { Urbano }\end{array}$ & 3 & 1 & 8 & 12 & 2 & 1 & 4 & 7 & 19 & 58 \\
\hline 22 & $\begin{array}{l}\text { Santa Clara Capitol } \\
\text { Line }\end{array}$ & & 1 & 4 & 5 & & 0 & 0 & 0 & 5 & 0 \\
\hline 23 & $\begin{array}{l}\text { Santa Clara Tasman } \\
\text { East Line }\end{array}$ & 3 & 4 & 2 & 9 & 2 & 1 & 0 & 3 & 12 & 33 \\
\hline 24 & $\begin{array}{l}\text { Santa Clara Tasman } \\
\text { West Line }\end{array}$ & 1 & 3 & 3 & 7 & 2 & 0 & -1 & 1 & 8 & 14 \\
\hline 25 & $\begin{array}{l}\text { Santa Clara Vasona } \\
\text { Line }\end{array}$ & & 1 & 5 & 6 & & 0 & 0 & 0 & 6 & 0 \\
\hline 26 & $\begin{array}{l}\text { Seattle Busway } \\
\text { Tunnel }\end{array}$ & 1 & 3 & 3 & 7 & 1 & 3 & 0 & 7 & 11 & 57 \\
\hline 27 & $\begin{array}{l}\text { St Louis Saint Clair } \\
\text { Corridor }\end{array}$ & 3 & 1 & 2 & 6 & 0 & 0 & 0 & 0 & 6 & 0 \\
\hline 28 & $\begin{array}{l}\text { Washington Largo } \\
\text { Extension }\end{array}$ & 3 & 1 & 4 & 8 & 2 & -1 & 0 & 1 & 9 & 13 \\
\hline \multicolumn{12}{|c|}{ Mean: 34} \\
\hline
\end{tabular}




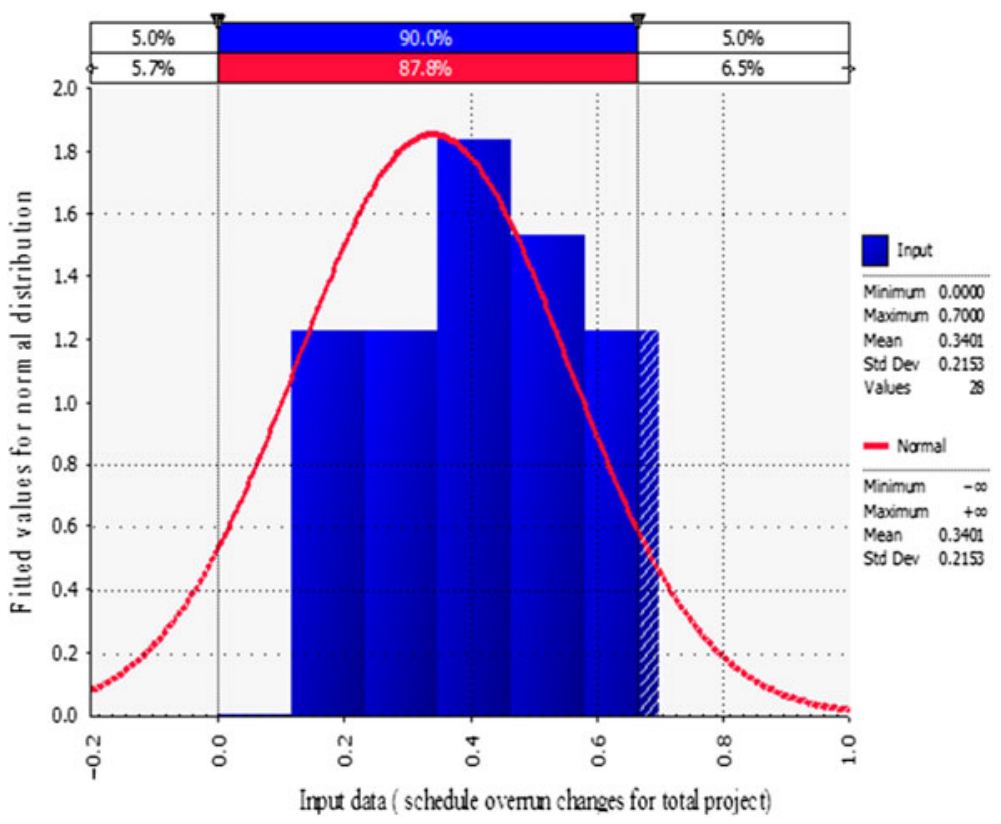

Fig. 1. Histogram of schedule growth at the completion of the project

explicit and systematic evaluation methods to achieve large-scale projects' objectives (Son, Rojas 2011).

Transportation projects are typical candidates that deserve thorough investigations for possible reasons of both schedule and cost growths. This twofold issue has been investigated at some depth (Bakshi, Touran 2009). It has been shown that there are many reasons for schedule delays and cost overruns including optimistic original estimates, lack of scope definition at the start of the project, increase in scope during project development phase due to pressure from project stakeholders, errors in estimation and lack of appropriate contingency budget (Booz Allen Hamilton Inc. 2005). In many construction projects, the owner plans for unexpected events that may affect project cost by adding a contingency to the estimated cost (Touran 2003). If the contingency is overestimated and allocated, the use of capital may be deemed inefficient and if it is underestimated, it contributes to increase the probability that the project may fail (Tseng et al. 2009). There are many factors affecting a project performance; disturbances in the supply of materials and equipment, irregular financing, design errors, inclement weather, equipment failures, inefficient contractors, administrative and legal disturbances, etc. (Rogalska, Hejducki 2007), and the risks in several infrastructural projects including road and railroad projects (Lam 1999). Construction delay and overrun is a critical function in construction of public projects and the time required to complete these projects is frequently greater than the time specified in the contract (Al-Momani 2000). It is clear that contingency is critical in scheduling and it can be developed for project schedule as a time buffer that is set aside to cope with uncertainties during project design and construction.

Several quantitative studies have been made to determine the project duration, schedule contingencies and time overruns; Bayesian belief networks to quantify the probability of construction delays (Luu et al. 2009), real options approach for contingency estimation (Tseng et al. 2009), and three-stage leastsquares technique to identify the factors that significantly affect cost and time overruns (Bhargava et al. 2010). Monte Carlo simulation has been used to estimate project contingency and allocate among project activities (Barraza 2011).

The estimation of highway project duration can be made on the basis of past experience or using historical data from similar projects in similar contractual circumstances (Irfan et al. 2011). They investigated the project duration on the basis of variables known at the planning phase such as planned cost, project and contract type, and then developed a model using data from the State of Indiana, spanning the years 1996-2001.

In this study, a probabilistic approach is proposed to calculate schedule contingency in transit projects. The objective is to estimate schedule contingencies for the different level of completion of a project and to achieve the project completion without delay. For this purpose, Joint Confidence Level-Probabilistic Calculator (JCL-PC) approach proposed by Butts and Linton (2009) is adopted as the probabilistic method. The method is modified and used for transportation projects and applied on a set of data obtained from Booz Allen Hamilton Inc. (2005) report. 

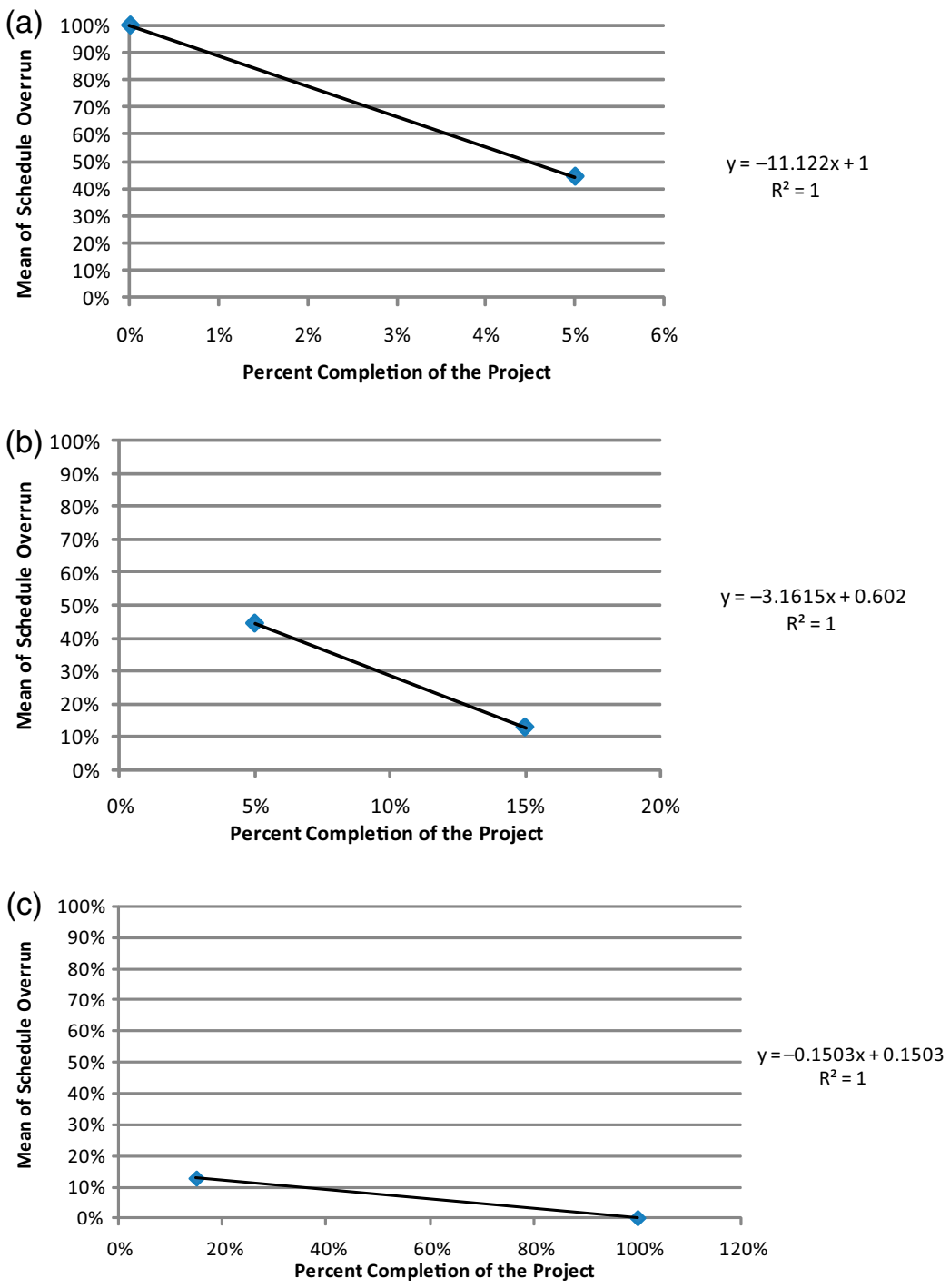

Fig. 2. Overview of contingency available in PE/FEIS phase (a); Overview of contingency remaining in FD phase (b); Overview of contingency remaining in Construction phase (c)

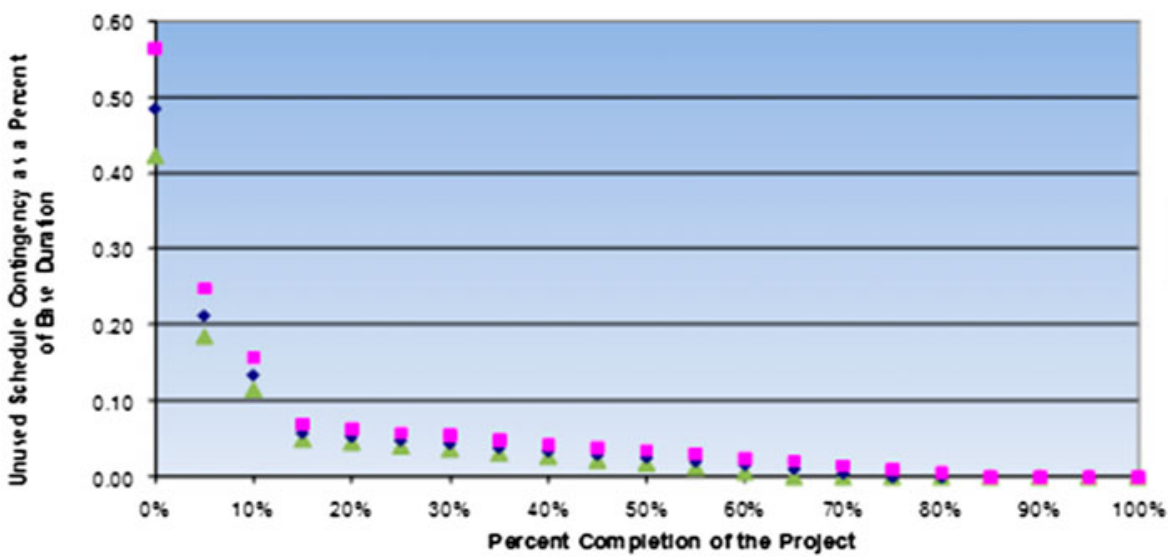

Fig. 3. Unused schedule contingency as a percent of base duration vs. project percent completion 


\begin{tabular}{|c|c|c|c|c|c|c|c|c|c|c|}
\hline \multirow[b]{2}{*}{ A } & \multicolumn{4}{|c|}{ Delays in phases (years) } & \multicolumn{3}{|c|}{ Cumulative phase delay/total project delay } & \multicolumn{3}{|c|}{ Schedule contingency at the end of phases } \\
\hline & $\mathrm{B}$ & $\mathrm{C}$ & $\mathrm{D}$ & $\mathrm{E}$ & $\mathrm{F}$ & G & $\mathrm{H}$ & I & $\mathrm{J}$ & $\mathrm{K}$ \\
\hline $\begin{array}{l}\text { Project } \\
\text { Number }\end{array}$ & $\begin{array}{l}\text { PE/ } \\
\text { FEIS }\end{array}$ & FD & Construction & $\begin{array}{c}\text { Total } \\
\text { project } \\
\text { delay }\end{array}$ & $\begin{array}{c}\text { PE/FEIS } \\
\text { (Col.B/ } \\
\text { Col.E) } \%\end{array}$ & $\begin{array}{c}\text { FD }([\text { Col.B }+ \\
\text { Col.C]/Col.E) } \%\end{array}$ & $\begin{array}{l}\text { Construction }([\mathrm{Col} . \mathrm{B}+ \\
\text { Col.C }+ \text { Col.D }] / \text { Col.E) } \%\end{array}$ & $\begin{array}{c}\text { PE/FEIS } \\
(1-\text { Col.F }) \%\end{array}$ & FD $(1-$ Col.G $) \%$ & $\begin{array}{l}\text { Construction } \\
(1-\text { Col.H) } \%\end{array}$ \\
\hline 1 & 0 & 0 & 4 & 4 & 0 & 0 & 100 & 100 & 100 & 0 \\
\hline 2 & 1 & 2 & 0 & 3 & 33 & 100 & 100 & 67 & 0 & 0 \\
\hline 3 & 4 & 0 & 4 & 8 & 50 & 50 & 100 & 50 & 50 & 0 \\
\hline 4 & 0 & 1 & 2 & 3 & 0 & 33 & 100 & 100 & 67 & 0 \\
\hline 5 & 1 & 2 & -1 & 2 & 50 & 150 & 100 & 50 & -50 & 0 \\
\hline 6 & 4 & 0 & 0 & 4 & 100 & 100 & 100 & 0 & 0 & 0 \\
\hline 7 & & 1 & 2 & 3 & 0 & 33 & 100 & 100 & 67 & 0 \\
\hline 8 & & 2 & 2 & 4 & 0 & 50 & 100 & 100 & 50 & 0 \\
\hline 9 & & 2 & 1 & 3 & 0 & 67 & 100 & 100 & 33 & 0 \\
\hline 10 & 3 & 1 & 1 & 5 & 60 & 80 & 100 & 40 & 20 & 0 \\
\hline 11 & 1 & 1 & 2 & 4 & 25 & 50 & 100 & 75 & 50 & 0 \\
\hline 12 & 3 & 1 & 0 & 4 & 75 & 100 & 100 & 25 & 0 & 0 \\
\hline 13 & 2 & 4 & 0 & 6 & 33 & 100 & 100 & 67 & 0 & 0 \\
\hline 14 & 4 & 3 & 0 & 7 & 57 & 100 & 100 & 43 & 0 & 0 \\
\hline 15 & & 0 & 0 & 0 & & & & & & \\
\hline 16 & & 2 & 0 & 2 & 0 & 100 & 100 & 100 & 0 & 0 \\
\hline 17 & 0 & 0 & 0 & 0 & & & & & & \\
\hline 18 & 1 & 3 & 0 & 4 & 25 & 100 & 100 & 75 & 0 & 0 \\
\hline 19 & 2 & 0 & -1 & 1 & 200 & 200 & 100 & -100 & -100 & 0 \\
\hline 20 & 2 & 0 & 2 & 4 & 50 & 50 & 100 & 50 & 50 & 0 \\
\hline 21 & 2 & 1 & 4 & 7 & 29 & 43 & 100 & 71 & 57 & 0 \\
\hline 22 & & 0 & 0 & 0 & & & & & & \\
\hline 23 & 2 & 1 & 0 & 3 & 67 & 100 & 100 & 33 & 0 & 0 \\
\hline 24 & 2 & 0 & -1 & 1 & 200 & 200 & 100 & -100 & -100 & 0 \\
\hline 25 & & 0 & 0 & 0 & & & & & & \\
\hline 26 & 1 & 3 & 0 & 4 & 25 & 100 & 100 & 75 & 0 & 0 \\
\hline 27 & 0 & 0 & 0 & 0 & & & & & & \\
\hline 28 & 2 & -1 & 0 & 1 & 200 & 100 & 100 & -100 & 0 & 0 \\
\hline
\end{tabular}

Notes: Mean 44, 13 and 0. 


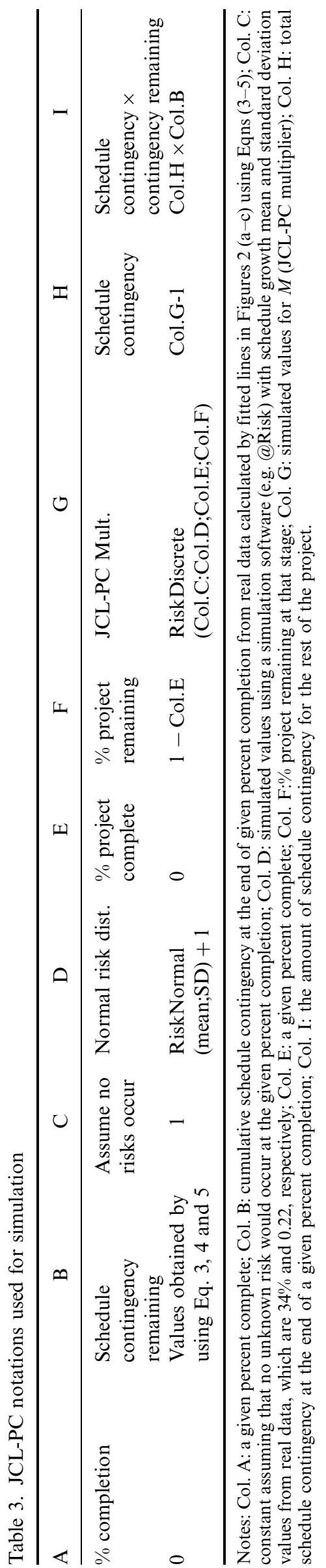

\section{JCL-PC approach}

In a NASA Cost Estimating Symposium, Butts and Linton (2009) presented an approach, which aims to provide guidelines for developing more accurate cost estimates for NASA projects. The objective is mathematically compensating the optimism bias inherent in NASA cost estimating activity. The optimism bias is handled by looking at the historical performance of projects completed in the past and assume that the effectiveness of the owner agency will be the same as was in previous projects and hence, the same level of cost overruns and schedule delays will happen in future projects. The method is called Joint Confidence Level-Probabilistic Calculator approach (JCL-PC) and is based on the hypothesis that, in the beginning phases of a project, there are many unknown risks and over time the project will have a high probability of exceeding estimated costs and scheduled duration (Butts, Linton 2009).

The JCL-PC equation developed through this holistic algorithm is used to correct the overly optimistic cost and schedule estimates in NASA projects. The aim is to define the probability that the actual cost and schedule will be equal or less than the targeted cost and schedule date. The lessons learned and the benefits obtained by using the proposed method have also been collected (NASA 2010). It basically helps to improve project planning by strengthening risk management through quantification of risks in terms of cost and schedule impacts. Enforcing scheduling best practices, JCL-PC provides the picture of the project ability to achieve cost and schedule goals, and to help the determination of schedule and cost reserves. At any confidence level, the project can be baselined or rebaselined for schedule analysis and rebudgeted for cost analysis.

In this approach, a histogram of cost or schedule overruns is used. A ratio is selected using a simulation approach such that it ensures that the established budget or schedule will not be exceeded with a specified confidence level (Touran, Zhang 2011). It is assumed that as the project progresses, optimism biases will fade and quantifiable risks become clearer.

In order to make the appropriate correction of the estimate at a specified confidence level, a multiplier is calculated in JCL-PC method from Eqn (1). Afterwards, the base estimate is multiplied by this multiplier $M$ and the required budget or schedule is estimated at a specified confidence level:

$$
\begin{gathered}
M=(1+z) \times 1 \times(\text { Percent complete }) \\
\text { projects required budget or duration }= \\
\quad M \times \text { projectbaseestimate. }
\end{gathered}
$$

In Eqn (1), the percent cost or schedule growth in previously completed similar projects is represented by $z$ value from distribution $\mathrm{Z}$. The sum of percent 
Table 4. JCL-PC notations used for simulation in the application

\begin{tabular}{|c|c|c|c|c|c|c|c|c|}
\hline A & $\mathrm{B}$ & $\mathrm{C}$ & $\mathrm{D}$ & $\mathrm{E}$ & $\mathrm{F}$ & G & $\mathrm{H}$ & I \\
\hline \multirow[t]{2}{*}{$\begin{array}{l}\% \\
\text { completion }\end{array}$} & $\begin{array}{l}\text { Schedule contingency } \\
\text { remaining }\end{array}$ & $\begin{array}{l}\text { Assume no } \\
\text { unknown risks } \\
\text { occur }\end{array}$ & $\begin{array}{c}\text { Normal risk dist. } \\
\text { (mean: } 0.34, \mathrm{SD}: \\
0.22 \text { ) }\end{array}$ & $\begin{array}{l}\% \text { project } \\
\text { completed }\end{array}$ & $\begin{array}{l}\% \text { project } \\
\text { remaining }\end{array}$ & JCL-PC Mult. & $\begin{array}{l}\text { Schedule } \\
\text { contingency }\end{array}$ & $\begin{array}{c}\text { Schedule } \\
\text { contingency } \times \\
\text { contingency remaining }\end{array}$ \\
\hline & $\begin{array}{l}-11.12 \times \text { Col.A }+1 \\
(\text { for PE/FEIS })-3.1615 \times \\
\text { Col.A }+0.602(\text { for FD) }- \\
0.1503 \times \text { Col.A }+0.1503 \\
(\text { for construction })\end{array}$ & & $\begin{array}{l}=\text { RiskNormal } \\
(0.34 ; 0.22)+1\end{array}$ & & $1-$ ColE & $\begin{array}{l}=\text { RiskDiscrete (Col.C: } \\
\text { Col.D;Col.E;Col.F) }\end{array}$ & $=$ Col.G -1 & $=$ Col. $\mathrm{H} \times$ Col. $\mathrm{B}$ \\
\hline 0 & 1.00 & 1 & 1.3401 & 0 & 100 & 1.3401 & 0.3401 & 0.3401 \\
\hline 5 & 0.44 & 1 & 1.3401 & 5 & 95 & 1.3401 & 0.3401 & 0.1510 \\
\hline 10 & 0.29 & 1 & 1.3401 & 10 & 90 & 1.3401 & 0.3401 & 0.0972 \\
\hline 15 & 0.13 & 1 & 1.3401 & 15 & 85 & 1.3401 & 0.3401 & 0.0435 \\
\hline 20 & 0.12 & 1 & 1.3401 & 20 & 80 & 1.3401 & 0.3401 & 0.0409 \\
\hline 25 & 0.11 & 1 & 1.3401 & 25 & 75 & 1.3401 & 0.3401 & 0.0383 \\
\hline 30 & 0.11 & 1 & 1.3401 & 30 & 70 & 1.3401 & 0.3401 & 0.0358 \\
\hline 35 & 0.10 & 1 & 1.3401 & 35 & 65 & 1.3401 & 0.3401 & 0.0332 \\
\hline 40 & 0.09 & 1 & 1.3401 & 40 & 60 & 1.3401 & 0.3401 & 0.0307 \\
\hline 45 & 0.08 & 1 & 1.3401 & 45 & 55 & 1.3401 & 0.3401 & 0.0281 \\
\hline 50 & 0.08 & 1 & 1.3401 & 50 & 50 & 1 & 0 & 0 \\
\hline 55 & 0.07 & 1 & 1.3401 & 55 & 45 & 1 & 0 & 0 \\
\hline 60 & 0.06 & 1 & 1.3401 & 60 & 40 & 1 & 0 & 0 \\
\hline 65 & 0.05 & 1 & 1.3401 & 65 & 35 & 1 & 0 & 0 \\
\hline 70 & 0.05 & 1 & 1.3401 & 70 & 30 & 1 & 0 & 0 \\
\hline 75 & 0.04 & 1 & 1.3401 & 75 & 25 & 1 & 0 & 0 \\
\hline 80 & 0.03 & 1 & 1.3401 & 80 & 20 & 1 & 0 & 0 \\
\hline 85 & 0.02 & 1 & 1.3401 & 85 & 15 & 1 & 0 & 0 \\
\hline 90 & 0.02 & 1 & 1.3401 & 90 & 10 & 1 & 0 & 0 \\
\hline 95 & 0.01 & 1 & 1.3401 & 95 & 5 & 1 & 0 & 0 \\
\hline 100 & 0 & 1 & 1.3401 & 100 & 0 & 1 & 0 & 0 \\
\hline
\end{tabular}


Table 5. Simulated unused contingency values as a percent of base duration using normal distribution

\begin{tabular}{|c|c|c|c|c|c|c|c|c|c|c|c|c|c|c|c|c|c|c|c|}
\hline $\begin{array}{l}\text { Project } \\
\text { completion } \%\end{array}$ & $5 \%$ & $10 \%$ & $15 \%$ & $20 \%$ & $25 \%$ & $30 \%$ & $35 \%$ & $40 \%$ & $45 \%$ & $50 \%$ & $55 \%$ & $60 \%$ & $65 \%$ & $70 \%$ & $75 \%$ & $80 \%$ & $85 \%$ & $90 \%$ & $95 \%$ \\
\hline 0 & -1.5 & 6.4 & 11.6 & 15.9 & 19.4 & 22.7 & 25.7 & 28.6 & 31.3 & 34.0 & 36.7 & 39.5 & 42.3 & 45.3 & 48.5 & 52.1 & 56.3 & 61.6 & 69.3 \\
\hline 5 & -0.6 & 0.0 & 3.0 & 5.5 & 7.5 & 9.1 & 10.7 & 12.0 & 13.3 & 14.5 & 15.8 & 17.1 & 18.5 & 19.8 & 21.3 & 22.9 & 24.8 & 27.1 & 30.5 \\
\hline 10 & -0.3 & 0.0 & 0.0 & 2.2 & 3.7 & 4.9 & 6.0 & 7.0 & 8.0 & 8.9 & 9.7 & 10.6 & 11.5 & 12.4 & 13.5 & 14.5 & 15.7 & 17.1 & 19.8 \\
\hline 15 & 0.0 & 0.0 & 0.0 & 0.1 & 1.2 & 1.8 & 2.3 & 2.8 & 3.2 & 3.7 & 4.1 & 4.6 & 4.9 & 5.4 & 5.9 & 6.3 & 6.9 & 7.7 & 8.6 \\
\hline 20 & 0.0 & 0.0 & 0.0 & 0.0 & 0.1 & 1.2 & 1.8 & 2.4 & 2.9 & 3.3 & 3.7 & 4.1 & 4.5 & 4.9 & 5.3 & 5.8 & 6.3 & 7.0 & 8.1 \\
\hline 25 & 0.0 & 0.0 & 0.0 & 0.0 & 0.0 & 0.1 & 1.0 & 1.7 & 2.3 & 2.7 & 3.2 & 3.6 & 4.0 & 4.4 & 4.9 & 5.3 & 5.8 & 6.5 & 7.5 \\
\hline 30 & 0.0 & 0.0 & 0.0 & 0.0 & 0.0 & 0.0 & 0.3 & 1.2 & 1.8 & 2.3 & 2.8 & 3.2 & 3.6 & 4.0 & 4.4 & 4.9 & 5.4 & 6.0 & 7.0 \\
\hline 35 & 0.0 & 0.0 & 0.0 & 0.0 & 0.0 & 0.0 & 0.0 & 0.2 & 1.1 & 1.8 & 2.3 & 2.7 & 3.1 & 3.5 & 3.9 & 4.3 & 4.9 & 5.5 & 6.3 \\
\hline 40 & 0.0 & 0.0 & 0.0 & 0.0 & 0.0 & 0.0 & 0.0 & 0.0 & 0.4 & 1.1 & 1.8 & 2.2 & 2.7 & 3.1 & 3.4 & 3.8 & 4.3 & 4.9 & 5.8 \\
\hline 45 & 0.0 & 0.0 & 0.0 & 0.0 & 0.0 & 0.0 & 0.0 & 0.0 & 0.0 & 0.5 & 1.2 & 1.7 & 2.2 & 2.6 & 3.0 & 3.4 & 3.8 & 4.3 & 5.2 \\
\hline 50 & 0.0 & 0.0 & 0.0 & 0.0 & 0.0 & 0.0 & 0.0 & 0.0 & 0.0 & 0.0 & 0.5 & 1.2 & 1.8 & 2.3 & 2.6 & 3.0 & 3.5 & 4.0 & 4.6 \\
\hline 55 & 0.0 & 0.0 & 0.0 & 0.0 & 0.0 & 0.0 & 0.0 & 0.0 & 0.0 & 0.0 & 0.0 & 0.5 & 1.2 & 1.7 & 2.1 & 2.5 & 3.0 & 3.4 & 4.2 \\
\hline 60 & 0.0 & 0.0 & 0.0 & 0.0 & 0.0 & 0.0 & 0.0 & 0.0 & 0.0 & 0.0 & 0.0 & 0.0 & 0.6 & 1.2 & 1.6 & 2.0 & 2.4 & 2.9 & 3.6 \\
\hline 65 & 0.0 & 0.0 & 0.0 & 0.0 & 0.0 & 0.0 & 0.0 & 0.0 & 0.0 & 0.0 & 0.0 & 0.0 & 0.0 & 0.6 & 1.1 & 1.5 & 2.1 & 2.5 & 2.9 \\
\hline 70 & 0.0 & 0.0 & 0.0 & 0.0 & 0.0 & 0.0 & 0.0 & 0.0 & 0.0 & 0.0 & 0.0 & 0.0 & 0.0 & 0.0 & 0.5 & 1.0 & 1.4 & 1.9 & 2.5 \\
\hline 75 & 0.0 & 0.0 & 0.0 & 0.0 & 0.0 & 0.0 & 0.0 & 0.0 & 0.0 & 0.0 & 0.0 & 0.0 & 0.0 & 0.0 & 0.0 & 0.6 & 1.0 & 1.5 & 1.9 \\
\hline 80 & 0.0 & 0.0 & 0.0 & 0.0 & 0.0 & 0.0 & 0.0 & 0.0 & 0.0 & 0.0 & 0.0 & 0.0 & 0.0 & 0.0 & 0.0 & 0.0 & 0.6 & 1.0 & 1.4 \\
\hline 85 & 0.0 & 0.0 & 0.0 & 0.0 & 0.0 & 0.0 & 0.0 & 0.0 & 0.0 & 0.0 & 0.0 & 0.0 & 0.0 & 0.0 & 0.0 & 0.0 & 0.0 & 0.7 & 1.0 \\
\hline 90 & 0.0 & 0.0 & 0.0 & 0.0 & 0.0 & 0.0 & 0.0 & 0.0 & 0.0 & 0.0 & 0.0 & 0.0 & 0.0 & 0.0 & 0.0 & 0.0 & 0.0 & 0.0 & 0.6 \\
\hline 95 & 0.0 & 0.0 & 0.0 & 0.0 & 0.0 & 0.0 & 0.0 & 0.0 & 0.0 & 0.0 & 0.0 & 0.0 & 0.0 & 0.0 & 0.0 & 0.0 & 0.0 & 0.0 & 0.0 \\
\hline 100 & 0.0 & 0.0 & 0.0 & 0.0 & 0.0 & 0.0 & 0.0 & 0.0 & 0.0 & 0.0 & 0.0 & 0.0 & 0.0 & 0.0 & 0.0 & 0.0 & 0.0 & 0.0 & 0.0 \\
\hline
\end{tabular}

remaining and percent complete is always $100 \%$ and refer to the project under consideration. Base estimate is project schedule (or cost) after all contingencies have been removed. These definitions indicate that as more of the project is completed, the required contingency becomes smaller for the remaining portion. One major issue with the JCL-PC approach is that for various levels of project completion, the delay distribution for $z$ remains the same. It is reasonable to assume that as project approaches completion, the delay distribution should represent smaller values because the magnitude of delays should become smaller. The authors of this paper have modified the JCL-PC approach to account for this important shortcoming of the NASA approach.

\section{The proposed approach in the context of transit projects}

In this study, 28 transit projects' historical data is used to show the proposed approach for establishing the project's schedule contingency. The data is obtained from Booz Allen Hamilton Inc. report (2005). The following phases of the project lifecycle are reported with their duration and delay data as listed in Table 1. The average duration of all projects for total, preliminary engineering, final design and construction phases are 8.4 years, 2.3 years, 2.7 years and 4.0 years respectively. These are completed transit projects in the United States characterized by three different mode types; heavy rail, light rail and bus way.
Project development phases can be defined as:

- Preliminary Engineering (PE)/Final Environmental Impact Statement (FEIS);

- Final Design (FD), which is at the end of design effort in traditional design-bid-build contracts and before going to bid;

- Construction.

Since the schedule growth is available for this set of projects, it is possible to construct the histogram of the distribution of schedule growth at the end of construction phase which actually reflects the real project completion times with delays (Fig. 1). It shows that the average schedule growth is $34 \%$ of the original duration and the standard deviation of the schedule growth is $22 \%$ (Fig. 1). Using Chi-square test of goodness of fit, a Normal Distribution is fitted to this data set.

The means of cumulative schedule growths are then calculated and the schedule contingency amount at the end of each phase is determined. Afterwards, these values are mapped against percent completions for all phases. It is assumed for the purpose of this study that PE/FEIS, FD and Construction phases refer to $5 \%, 15 \%$ and $100 \%$ completions respectively and the mapping is conducted for each phase independently (Touran, Zhang 2011). The average schedule contingencies at the end of PE/FEIS, FD and Construction phases are determined as $44 \%, 13 \%$ and $0 \%$ respectively as shown in Table 2. Three fitted sets of data against 
percent completions $(0 \%, 5 \%, 15 \%$ and $100 \%)$ are shown in Figures $2(\mathrm{a}-\mathrm{c})$.

The other percent completion levels can be estimated by using the mean lines of schedule growth at the end of each phase $(\mu)$ which are fitted according to the data points expressed above and calculated depending on the corresponding phase interval.

The separate equations for determining the mean values for the PE/FEIS, FD and Construction phases are expressed below in Eqns (3-5):

$$
\begin{gathered}
\mu_{P E / F E I S}=-11.122 x+1 ; \\
\mu_{F D}=-3.1615 x+0.602 ; \\
\mu_{\text {Construction }}=-1503 x+0.1503,
\end{gathered}
$$

where $x$ is percent completion for the project, expressed in decimal format.

Eqns (3), (4) and (5) can be used to calculate the means of schedule contingency remaining at a given percent completion between 0-0.05 (PE/FEIS), 0.050.15 (FD) and $0.15-1$ (Construction) respectively, assuming linear changes in delay during each of these phases.

For different completion percentages, the appropriate normal distribution value is used to determine the values of $M$ which is the JCL-PC multiplier (Eqn 1). A distribution for $M$ is simulated for each percentage point and then used to calculate the value of $M$ for the specified confidence levels as proposed by Butts and Linton (2009). The amount of the schedule growth at a given percent completion is then determined by multiplying the total schedule contingency value (obtained by using JCL-PC multiplier) and the schedule contingency remaining at that stage. A sample table is provided in Table 3 in order to show the notations that are used in the calculations.

\section{Application}

In order to use the lines fitted, a hypothetical transit project is considered and it is assumed that the owner wants to establish a schedule contingency at different confidence levels as a percentage of base duration. Base duration is the established project duration excluding all contingencies. If the estimate is prepared at the end of PE/FEIS phase (approximately 5\% completion), the simulation results in Table 5 show that $18.5 \%, 21.3 \%, 24.8 \%$ schedule contingency is determined (as the percentage of the base estimate) with a probability of $65 \%, 75 \%$ and $85 \%$, respectively. If this estimate is made for $50 \%$ completion, then the amount will be about $1.8 \%, 2.6 \%$ and $3.5 \%$ of the base duration, respectively. It is obvious that as the project progresses, the schedule contingency that should be added to the base estimate decreases. This pattern is observed in simulation results and it is shown as an example in Figure 3. The JCL notations used for simulation in the application and JCL multipliers determined by simulation are presented in Table 4. All of the simulation results including these values generated for different levels of project completions vs. probabilities are shown in Table 5. It should be noted that the aim of the proposed method is to establish sufficient contingency to ensure the project completion without any delay.

\section{Summary and conclusions}

In this paper, a methodology is proposed to analyze the project schedule contingency for transit projects by considering various stages of project completion for different contingency levels. It considers the usage of schedule contingency as the project progresses. It takes into account the variations of both the mean values and standard deviations of time extensions at different percent completions. Since the calculations are based on actual data set of transit projects, the schedule growth rates can be obtained more accurately for desired confidence levels. This would provide opportunity to all project parties to make more realistic estimates in their schedules and plans during various stages of the project; and be prepared to take necessary action in case the available schedule contingency falls below reasonable levels.

\section{References}

Ahmed, S. M.; Azhar, S.; Kappagantula, P.; Gollapudi, D. 2003. Delays in construction: a brief study of Florida construction industry, in ASC Proceedings of the 39th Annual Conference, 10-12 April, 2003, Clemson University, Clemson, South Carolina, 257-266.

Al-Momani, A. H. 2000. Construction delay: a quantitative analysis, International Journal of Project Management 18(1): 51-59. http://dx.doi.org/10.1016/S0263-7863(98)00060-X

Assaf, S. A.; Al-Hejji, S. 2006. Causes of delay in large construction projects, International Journal of Project Management 24(4): 349-357. http://dx.doi.org/10.1016/j.ijproman.2005.11.010

Bakshi, P.; Touran, A. 2009. Comparison of current probabilistic approaches for budget estimate for transportation projects, in Proc. of the 7th International Probabilistic Workshop, 2009, Delft, Netherlands, 479-490.

Barraza, G. A. 2011. Probabilistic estimation and allocation of project time contingency, Journal of Construction Engineering and Management ASCE 137(4): 259-265. http://dx.doi.org/10.1061/(ASCE)CO.1943-7862. 0000280

Bhargava, A.; Anastasopoulos, P. C.; Labi, S.; Sinha, K. C.; Mannering, F. L. 2010. Three-stage least-squares analysis of time and cost overruns in construction contracts, Journal of Construction Engineering and Management ASCE 136(11): 1207-1218. http://dx.doi.org/10.1061/(ASCE)CO.1943-7862. 0000225

Booz Allen Hamilton, Inc. 2005. Managing capital costs for major federally funded public transportation projects. TCRP web-only document 31 . Washington, DC: TRB. 
Butts, G.; Linton, K. 2009. The joint confidence level paradox a history of denial, in NASA Cost Symposium. Presentation paper, Kansas City, MO, 109.

Capka, J. R. 2004. Megaprojects - they are a different breed [online], [cited 27 June 2011]. Available from Internet: http://www.fhwa.dot.gov/publications/publicroads/04 jul/01.cfm.

Irfan, M.; Khurshid, B. M.; Anastasopoulos, P.; Labi, S.; Moavenzadeh, F. 2011. Planning-stage estimation of highway project duration on the basis of anticipated project cost, project type and contract type, International Journal of Project Management 29(1): 78-92.

http://dx.doi.org/10.1016/j.ijproman.2010.01.001

Kaliba, C.; Muya, M.; Mumba, K. 2009. Cost escalation and schedule delays in road construction projects in Zambia, International Journal of Project Management 27(5): 522-531.

http://dx.doi.org/10.1016/j.ijproman.2008.07.003

Lam, P. T. I. 1999. A sectoral review of risks associated with major infrastructure projects, International Journal of Project Management 17(2): 77-87. http://dx.doi.org/10.1016/S0263-7863(98)00017-9

Luu, V. T.; Kim, S.; Tuan, N. V.; Ogunlana, S. O. 2009. Quantifying schedule risk in construction projects using Bayesian belief networks, International Journal of Project Management 27(1): 39-50.

http://dx.doi.org/10.1016/j.ijproman.2008.03.003
NASA. 2010. Joint confidence level (JCL) FAQ [online], [cited 27 June 2011]. Available from Internet: http:// www.nasa.gov/pdf/394931main_JCL_FAQ_10_12_09. pdf.

Rogalska, M.; Hejducki, Z. 2007. Time buffers in construction process scheduling, Journal of Civil Engineering and Management 13(2): 143-148.

Son, J.; Rojas, E. M. 2011. Impact of optimism bias regarding organizational dynamics on project planning and control, Journal of Construction Engineering and Management ASCE 137(2): 147-157. http://dx.doi.org/10.1061/(ASCE)CO.1943-7862. 0000260

Touran, A. 2003. Probabilistic model for cost contingency, Journal of Construction Engineering and Management ASCE 129(3): 280-284. http://dx.doi.org/10.1061/(ASCE)0733-9364(2003) 129:3(280)

Touran, A.; Zhang, Y. 2011. Contingency vs. percent completion in infrastructure projects, in Proc. of Modern Methods and Advances in Structural Engineering and Construction, ISEC-6, 2011, Zurich, Switzerland, 99-104.

Tseng, C.-L.; Zhao, T.; Fu, C. C. 2009. Contingency estimation using a real options approach, Construction Management and Economics 27(11): 1073-1087. http://dx.doi.org/10.1080/01446190903222411

Asli Pelin GURGUN. She is an Assistant Professor in the Department of Civil Engineering at Okan University, in Istanbul, Turkey. Her research interests cover risk analysis, risk management, simulation, decision making, project management, project delivery systems green construction.

Ye ZHANG. He is a PhD candidate in the Department of Civil \& Environmental Engineering, Northeastern University, Boston, USA. His research interests cover project management, construction management, risk analysis and management, simulation, and cost estimating.

Ali TOURAN. He is a Professor in the Department of Civil and Environmental Engineering at Northeastern University, in Boston, USA, where he is the coordinator of the graduate program in Construction Management. $\mathrm{He}$ is the author or co-author of more than 90 technical papers in journals and conference proceedings. Dr Touran's research is in the area of risk analysis of infrastructure projects, simulation, and project delivery systems. 